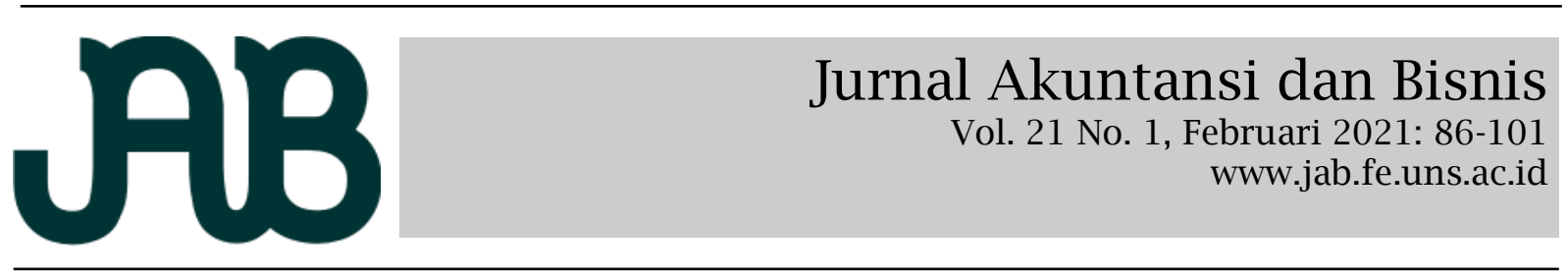

\title{
KEBIJAKAN AKUNTANSI HERITAGE ASSETS TERKAIT STANDAR PSAP NOMOR 07 TAHUN 2010
}

\author{
RENDAH OKTAVIANTI NINGTYAS (rendah.oktavianti.ningtyas-2017@feb.unair.ac.id) \\ HAMIDAH
}

Program Studi Akuntansi, Fakultas Ekonomi dan Bisnis, Universitas Airlangga, Indonesia

\begin{abstract}
A B S T R A C T
This study aims to analyze and describe the accounting policy for heritage assets, and analyze the staffs of Balai Pemuda comprehension according to the accounting policy for heritage assets according to PSAP Nomor 07 Tahun 2010 (a case study of Balai Pemuda Surabaya). This study uses a qualitative method with a case study approach. The results show that the staff has understood the definition of heritage assets according to PSAP Nomor 07 Tahun 2010. However, the staff still associate the characteristics with a cultural heritage based on Undang-Undang Nomor 11 Tahun 2010. The Surabaya City Government, through the financial reports, has implemented the accounting treatment for heritage assets of Balai Pemuda according to PSAP Nomor 07 Tahun 2010. Nevertheless, disclosure has not been in line with the standard. The comprehension of the staff is still at a different level and not all of them understand the accounting treatment as presented in the financial statements and PSAP Nomor 07 Tahun 2010.

Keywords: heritage asset accounting, PSAP Nomor 07 Tahun 2010, comprehension of the staff entity, historical buildings

Penelitian ini bertujuan untuk menganalisis dan mendeskripsikan kebijakan akuntansi heritage assets, serta menganalisis pemahaman pengelola balai pemuda akan kebijakan akuntansi heritage assets sesuai PSAP Nomor 07 Tahun 2010 (studi kasus Balai Pemuda Surabaya). Penelitian ini menggunakan metode kualitatif dengan pendekatan studi kasus. Hasil penelitian menunjukkan bahwa pengelola telah memahami definisi heritage assets sesuai PSAP Nomor 07 Tahun 2010. Namun masih mengaitkan karakteristiknya dengan cagar budaya berdasarkan UU Nomor 11 Tahun 2010. Pemerintah Kota Surabaya melalui laporan keuangan telah menerapkan perlakuan akuntansi heritage assets Balai Pemuda Surabaya sesuai PSAP Nomor 07 tahun 2010. Namun, untuk pengungkapan belum sejalan dengan standar. Pemahaman pengelola masih berada pada tingkat yang berbeda-beda dan tidak semua pengelola memahami perlakuan akuntansi sebagaimana telah disajikan di laporan keuangan dan PSAP Nomor 07 Tahun 2010.

Kata kunci: akuntansi heritage assets, PSAP Nomor 07 Tahun 2010, pemahaman entitas pengelola, bangunan bersejarah
\end{abstract}

\section{PENDAHULUAN}

Indonesia adalah negara dengan jumlah populasi 250 juta serta dikategorikan sebagai salah satu negara dengan jumlah penduduk terpadat (Lukman, 2020). Tidak hanya dikenal dengan populasinya yang padat, Indonesia juga dikenal akan keberagaman sumber daya alam, etnis, serta budaya. Keberagaman tersebut didukung dengan melimpahnya kekayaan cagar budaya di berbagai wilayah di seluruh Indonesia. Atas data yang diperoleh pada laman cagarbudaya.kemdikbud.go.id dinyatakan bahwa hingga tahun 2020 menunjukkan banyaknya objek cagar budaya yang telah diverifikasi yaitu sebanyak 49.788 objek.

Banyaknya cagar budaya yang dimiliki oleh Indonesia tentunya juga menjadi tanggung jawab bagi pemerintah untuk melakukan pencatatan akuntansi. Terlebih sejak adanya perubahan sistem pelaporan keuangan menjadi akrual, entitas sektor publik dituntut untuk menjadi lebih bertanggung jawab terhadap stakeholder, dan meningkatkan pelaporan keuangan menjadi lebih informatif (Darmawan, Yadnyana \& Sudana, 2017).

Pada kenyataannya, identifikasi, penilaian dan pengakuan aset tetap di sektor publik bukanlah tugas yang mudah 
karena aset tersebut sudah ada selama beberapa dekade dan telah diperoleh dengan cara yang berbeda (Ouda, 2005). Ouda (2014) juga menyatakan bahwa dari beberapa jenis aset tetap, yang paling sulit untuk diidentifikasi dan dinilai adalah heritage assets karena dianggap memiliki karakteristik yang spesifik. Tidak adanya standar khusus sektor publik untuk heritage assets, juga membuat pemerintah mengalami kesulitan dalam melakukan pengakuan dan pengukuran (Anessi-pessina, Cattolica \& Steccolini, 2020). Berdasarkan atas pengalaman berbagai negara, perlakuan akuntansi heritage assets juga menimbulkan berbagai tantangan dan perdebatan dalam perlakuan akuntansinya (Basnan, Salleh, Ahmad, Harun \& Upawi, 2015).

Perdebatan ini membahas apakah heritage assets sebaiknya diakui sebagai aset atau tidak. Barton (2006) berpendapat bahwa tidak adanya manfaat ekonomi yang diberikan serta manfaatnya dapat dinikmati oleh warga negara secara gratis oleh karena itu heritage assets harus diperlakukan secara terpisah dari operasi aset dan tidak boleh dilaporkan dalam laporan keuangan. Widodo, Hanun \& Wulandari (2020); Wulandari dan Utama (2017) berpendapat bahwa heritage assets merupakan aset, dikarenakan heritage assets memiliki sesuatu yang bernilai dan melekat pada objek tersebut.

Beberapa peneliti juga berpendapat bahwa penilaian dalam heritage assets sebaiknya tidak dilaksanakan karena tidak adanya aspek ekonomi dan nilai esensial terkait dengan nilai sejarah, sains, pendidikan, agama, dan/atau budaya (Widodo et al., 2020). Tidak adanya pemberian nilai juga dikarenakan bahwa semakin lama lifes dari sebuah aset bersejarah dianggap tak terbatas (Wulandari dan Utama, 2017). Wild (2013) berpendapat lain, bagi heritage assets yang tidak hanya memberikan nilai budayanya saja, namun juga memiliki motif keuntungan dan peningkatan kekayaan, seharusnya dapat diukur dengan andal.

Beberapa peneliti juga berbeda pendapat mengenai apakah seharusnya heritage assets hanya cukup diungkapkan di Catatan atas Laporan Keuangan (CaLK) atau juga perlu untuk disajikan di neraca. Woon,
Chatterjee \& Cordery (2019); Ouda (2014) berpendapat bahwa tidak adanya manfaat ekonomi yang diperoleh, sebaiknya heritage assets tidak disajikan pada neraca namun hanya cukup diungkapkan di CaLK. Ellwood dan Greenwood (2015) memiliki pendapat lain bahwa adanya nilai keuangan pada heritage assets dan disajikannya di neraca hanya bertujuan untuk memastikan bahwa pengelolaan keuangan dan pengelolaan heritage assets telah dilakukan dan disajikan dengan baik, serta tidak sepenuhnya menghapuskan nilai budayanya.

Dewan Standar Akuntansi (ASB) mengeluarkan FRS 30 terkait dengan heritage assets menyatakan bahwa bahwa heritage assets dapat mewujudkan potensi layanan (budaya, pendidikan, pengajaran, penelitian) serta arus kas masuk bagi entitas pemerintah, seharusnya heritage assets dapat disajikan di laporan keuangan dengan nilai. Namun, pada beberapa penelitian masih mengalami perdebatan dan tidak semua organisasi telah melakukan penilaian atas heritage assets yang memiliki potensi layanan dan arus kas.

PSAP Nomor 07 Tahun 2010 menyatakan bahwa entitas pemerintah tidak diharuskan menyajikan aset bersejarah (heritage assets) di neraca, namun aset tersebut harus diungkapkan dalam catatan atas laporan keuangan. Kemudian dilanjutkan dengan PSAP Nomor 07 Tahun 2010 paragraf 71 yaitu beberapa aset bersejarah juga memberikan potensi manfaat lainnya kepada pemerintah selain nilai sejarahnya, sebagai contoh bangunan bersejarah digunakan untuk ruang perkantoran. Untuk kasus tersebut, aset ini akan diterapkan prinsip-prinsip yang sama seperti aset tetap lainnya.

Namun demikian, penyajian atas bangunan bersejarah dengan nilai masih belum disertai dengan pengungkapan unit secara rinci pada CaLK. Berdasarkan pada kondisi di Indonesia, pemanfaatan heritage assets tidak hanya dari segi budaya dan sosial, namun juga memiliki nilai komersial yang berakibat pada arus kas masuk daerah. Seharusnya, pemerintah daerah di Indonesia dapat menyajikan heritage assets dengan nilai di laporan keuangan dan 
dapat mengembangkan dan melibatkan berbagai indikator pengukuran yang relevan (Biondi dan Lapsley, 2010; Wild, 2013). PSAP Nomor 07 Tahun 2010 juga menyatakan bahwa seharusnya aset bersejarah diungkapkan

secara rinci, antara lain nama, jenis, kondisi, dan lokasi aset dimaksud. Prinsip serta metode penilaian dan pengukuran aset bersejarah yang telah disajikan pada neraca seharusnya juga disertakan penjelasan pada CaLK, terlebih ada banyak jenis nilai terkait ekonomi, budaya, politik, estetika, dan berbagai jenis pengukuran aset bersejarah (Ellwood dan Greenwood, 2015).

Adanya perlakuan akuntansi yang tepat untuk heritage assets seharusnya juga disertai dengan pengetahuan dan pemahaman entitas pengelola terkait standar akuntansi. Untuk menemukan bentuk perlakuan akuntansi heritage assets yang tepat seharusnya pemerintah Indonesia terus meningkatkan pemahaman entitas pemerintah agar nantinya dapat memudahkan dalam mengetahui aspek ekonomi dari heritage assets (Darmawan et al., 2017).

Penelitian ini menarik untuk dilakukan karena penelitian sebelumnya masih memperdebatkan perlakuan akuntansi heritage assets, apakah sebaiknya diperlakukan seperti aset tetap pada umumnya atau diperlakukan secara khusus (Woon et al., 2019; Ouda, 2014). Adanya PSAP Nomor 07 Tahun 2010 menyatakan bahwa beberapa aset bersejarah juga memberikan potensi manfaat lainnya kepada pemerintah selain nilai sejarahnya, sebagai contoh bangunan bersejarah digunakan untuk ruang perkantoran. Untuk kasus tersebut, aset ini akan diterapkan prinsip yang sama seperti aset tetap lainnya. Kedua, penelitian sebelumnya belum pernah membahas terkait pemahaman pengelola entitas atas kebijakan akuntansi heritage assets secara terperinci mulai dari pengakuan, pengukuran, penilaian, penyajian, dan pengungkapan. Penelitian ini menganalisis dan mendeskripsikan atas pemahaman pengelola atas kebijakan akuntansi heritage assets atas tingkatan pemahaman berdasarkan teori taksonomi bloom.

Untuk mendapat gambaran secara realistis, penelitian ini difokuskan pada perlakuan akuntansi heritage assets Balai Pemuda Surabaya. Pemilihan obyek tersebut dikarenakan Balai Pemuda merupakan salah satu heritage assets di Kota Surabaya yang memiliki nilai sosial tinggi, sebagai penunjang kegiatan operasional, dan berkontribusi terhadap pendapatan asli daerah. Adanya arus kas masuk dari heritage assets bagi Pemerintah Kota Surabaya, seharusnya perlakuan akuntansi Balai Pemuda Surabaya dapat dilakukan secara tepat, baik pengakuan, pengukuran, penilaian, penyajian, dan pengungkapan.

Berdasarkan atas penjelasan tersebut, tujuan penelitian ini adalah menganalisis dan mendeskripsikan kebijakan akuntansi terkait pengakuan, pengukuran, penilaian, penyajian, dan pengungkapan heritage assets sesuai PSAP Nomor 07 Tahun 2010 (studi kasus Balai Pemuda Surabaya). Serta, tujuan kedua yaitu menganalisis pemahaman pengelola akan kebijakan akuntansi terkait pengakuan, pengukuran, penilaian, penyajian, dan pengungkapan heritage assets sesuai PSAP Nomor 07 Tahun 2010 (studi kasus Balai Pemuda Surabaya).

\section{TINJAUAN PUSTAKA \\ Heritage assets}

PSAP Nomor 07 Tahun 2010 menyatakan bahwa beberapa aset tetap dijelaskan sebagai aset bersejarah dikarenakan kepentingan budaya, lingkungan, dan sejarah. Berkaitan dengan pengertian heritage assets, masyarakat Indonesia terutama para sejarawan dan arkeolog masih sering kali mendefinisikan heritage assets sebagai cagar budaya. UndangUndang No 11 Tahun 2010 menyatakan bahwa cagar budaya adalah warisan budaya bersifat kebendaan berupa benda cagar budaya, bangunan cagar budaya, struktur cagar budaya, situs cagar budaya, dan kawasan cagar budaya di darat dan atau di air yang perlu dilestarikan keberadaannya karena memiliki nilai penting bagi sejarah, ilmu pengetahuan, pendidikan, agama, dan atau kebudayaan melalui proses penetapan. 


\section{Karakteristik Heritage assets}

PSAP Nomor 07 Tahun 2010 menjelaskan kriteria aset yang tergolong dalam aset warisan diantaranya, yaitu: a) Nilai kultural, lingkungan, pendidikan, dan sejarahnya tidak mungkin secara penuh dilambangkan dengan nilai keuangan berdasarkan harga pasar; b) Peraturan dan hukum yang berlaku melarang atau membatasi secara ketat pelepasannya untuk dijual; c) Tidak mudah untuk diganti dan nilainya akan terus meningkat selama waktu berjalan walaupun kondisi fisiknya semakin menurun; d) Sulit untuk mengestimasikan masa manfaatnya. Untuk beberapa kasus dapat mencapai ratusan tahun.

\section{Jenis-Jenis Heritage assets}

PSAP Nomor 07 Tahun 2010 tidak menjelaskan terkait dengan jenis-jenis heritage assets. Penjelasan jenis-jenis heritage assets tercantum dalam FRS 15 tangible fixed assets (Ouda, 2014). Heritage assets dibagi menjadi dua yaitu operational heritage assets dan non-operational heritage assets. Operational heritage assets adalah aset yang digunakan selain untuk tujuan pemeliharaan warisan nasional (misalnya bangunan warisan dengan ruang kantor, taman). Operational heritage assets nilainya akan dikapitalisasi misalnya bangunan terdaftar yang digunakan untuk akomodasi kantor, akan dinilai dengan dasar yang sama dengan aset operasional lainnya. Nonoperational heritage assets adalah aset yang hanya digunakan untuk dilestarikan sebagai kepercayaan untuk generasi mendatang, contohnya yaitu koleksi museum dan galeri, karya seni lainnya, arsip nasional, serta situs arkeologi, reruntuhan, situs pemakaman, monumen, dan patung.

\section{Pengakuan Heritage assets}

Peraturan Pemerintah 71 Tahun 2010 mendefinisikan pengakuan merupakan proses penetapan terpenuhinya kriteria pencatatan suatu kejadian atau peristiwa dalam catatan akuntansi sehingga akan menjadi bagian yang melengkapi unsur aset, kewajiban, ekuitas, pendapatan-LRA, belanja, pembiayaan, pendapatan-LO, dan beban, sebagaimana akan termuat pada laporan keuangan entitas pelaporan yang bersangkutan.

Berdasarkan atas PSAP 07 Tahun 2010, Indonesia mengakui heritage assets sebagai aset. Sebagaimana dijelaskan bahwa suatu aset diakui sebagai aset tetap apabila memenuhi kriteria: 1) Berwujud; 2) Mempunyai masa manfaat lebih dari 12 (dua belas) bulan; 3) Biaya perolehan aset dapat diukur secara andal; 4) Tidak dimaksudkan untuk dijual dalam operasi normal entitas; 5) Diperoleh atau dibangun dengan maksud untuk digunakan.

\section{Pengukuran Heritage assets}

Pengukuran adalah tolak ukur yang dinyatakan dalam nilai moneter dan pengukuran memiliki tingkat keyakinan yang tinggi atas harta, utang, modal, pendapatan, serta biaya (Soetedjo, 2009: 36). Wild (2013) menegaskan bahwa pemerintah seharusnya dapat mengembangkan dan melibatkan indikator pengukuran yang relevan untuk heritage assets yang digunakan dalam mendapatkan keuntungan dan peningkatan kekayaan. Anessi-pessina dkk. (2020); Stanton dan Stanton (1997) menyatakan pendapat lain bahwa tidak adanya kewajiban untuk mengukur aset bersejarah dikarenakan sering kali basis pengukuran yang digunakan masih kurang tepat, sehingga dapat berdampak negatif pada pelaporan keuangan pemerintah, oleh sebab itu sebaiknya pemberian nilai tidak diberikan pada heritage assets. Tidak adanya nilai dalam heritage assets juga karena tidak adanya aspek ekonomi dan nilai esensial berupa nilai sejarah, sains, pendidikan, agama, dan/atau budaya tidak bisa dinilai (Widodo et al., 2020)

PSAP Nomor 07 Tahun 2010 paragraf 20 menyatakan bahwa aset tetap dinilai dengan biaya perolehan. Apabila penilaian aset tetap dengan menggunakan biaya perolehan tidak memungkinkan maka nilai aset tetap didasarkan pada nilai wajar pada saat perolehan.

\section{Penilaian Heritage assets}

Penilaian adalah penentuan jumlah rupiah yang nantinya harus dilampirkan pada setiap elemen atau postingan pada pernyataan keuangan, penilaian berfungsi 
untuk mewakili atribut pos aset yang terkait dengan tujuan keuangan (Widodo et al., 2020).

PSAP Nomor 07 Tahun 2010 paragraf 23-24 menyatakan barang berwujud yang memenuhi kualifikasi untuk diakui sebagai suatu aset dan dikelompokkan sebagai aset tetap, pada awalnya harus diukur berdasarkan biaya perolehan. Bila aset tetap diperoleh dengan tanpa nilai, biaya aset tersebut adalah sebesar nilai wajar pada saat aset tersebut diperoleh. Serta diperjelas dalam PSAP Nomor 07 paragraf 49 bahwa pengeluaran setelah perolehan awal suatu aset tetap yang memperpanjang masa manfaat atau yang kemungkinan besar memberi manfaat ekonomi di masa yang akan datang dalam bentuk kapasitas, mutu produksi, atau peningkatan standar kinerja, harus ditambahkan pada nilai tercatat aset yang bersangkutan. Serta besaran atas kapitalisasi tersebut ditentukan dalam kebijakan akuntansi suatu entitas. Kapitalisasi biaya dimaksud pada paragraf 49 harus ditetapkan dalam kebijakan akuntansi suatu entitas berupa kriteria seperti pada paragraf 49 dan/atau suatu batasan jumlah biaya (capitalization thresholds) tertentu untuk dapat digunakan dalam penentuan apakah suatu pengeluaran harus dikapitalisasi atau tidak.

\section{Penyajian Heritage assets}

Adanya nilai keuangan pada heritage assets juga hanya bertujuan untuk memastikan bahwa pengelolaan keuangan dan pengelolaan heritage assets telah dilakukan dan disajikan dengan baik, serta tidak sepenuhnya menghapuskan nilai budayanya (Ellwood dan Greenwood, 2015). Penyajian heritage assets di neraca juga untuk memenuhi kebutuhan pengguna informasi (Micallef dan Peirson, 1997; Rowles, 1991).

Aset modal dengan atribut yang mirip dengan barang publik, seperti aset warisan, tidak boleh dikapitalisasi dan dimasukkan dalam laporan posisi keuangan (Christiaens et al., 2012 ; Woon et al., 2019). Ouda (2014) adanya penyajian heritage assets dalam neraca dapat menyesatkan para pengguna laporan keuangan. Hal ini dikarenakan heritage assets hanya memiliki tujuan untuk dipegang serta dipelihara terutama untuk kontribusi terhadap pengetahuan dan budaya.

PSAP Nomor 07 Tahun 2010 menyatakan bahwa pernyataan ini tidak mengharuskan pemerintah untuk menyajikan aset bersejarah (heritage assets) di neraca namun aset tersebut harus diungkapkan dalam CaLK. Namun apabila heritage assets memberikan potensi manfaat lainnya, maka akan diterapkan prinsip-prinsip yang sama seperti aset tetap lainnya.

\section{Pengungkapan Heritage assets}

Pengungkapan lengkap adalah laporan keuangan menyajikan secara lengkap informasi yang dibutuhkan oleh pengguna. Informasi yang dibutuhkan oleh pengguna laporan keuangan dapat ditempatkan pada lembar muka (on the face) laporan keuangan atau CaLK (PSAP Nomor 4 Tahun 2010).

PSAP Nomor 07 Tahun 2010 paragraf 83 menjelaskan bahwa aset bersejarah diungkapkan secara rinci, antara lain nama, jenis, kondisi, dan lokasi aset dimaksud.

\section{Pemahaman Entitas Pengelola}

Pemahaman entitas pengelola dibutuhkan agar pengelola dapat mengerti dan memahami bagaimana proses dan pelaksanaan perlakuan akuntansi heritage assets mulai dari pengakuan, pengukuran, penilaian, penyajian, dan pengungkapan.

Berdasarkan atas taksonomi Bloom, pengetahuan merupakan level terendah dari ranah kognitif. Pengetahuan didefinisikan bahwa individu baru sebatas berupa mengingat kembali atas materi yang telah didapatkan. Kemampuan yang dimaksud pada tingkatan ini yaitu berupa mengetahui sekaligus menyampaikan ingatan berupa menyebutkan dan menyatakan (Bloom, 1956: 62).

Apabila tingkat tahu telah dilewati, maka tingkat kedua adalah pemahaman. Pemahaman diartikan sebagai suatu kemampuan untuk memahami materi. Bloom (1956: 89) membedakan pemahaman menjadi tiga kategori yaitu: tingkat terendah adalah pemahaman terjemah, in- 
dividu mengkomunikasikan ke dalam bahasa lain, istilah lain, atau menjadi bentuk lain, dan melibatkan pemberian makna. Tingkat kedua adalah pemahaman interpretasi, yaitu individu harus mampu menjelaskan, memahami dan mengerti sesuatu secara keseluruhan pada setiap materi. Tingkat ketiga atau tingkat tertinggi adalah pemahaman ekstrapolasi, yaitu adanya pemikiran atau prediksi individu atas kondisi yang telah dijelaskan, dan memungkinkan melibatkan pembuatan kesimpulan sehubungan dengan implikasi, konsekuensi, akibat, dan efek sesuai dengan kondisi yang dijelaskan dalam komunikasi.

\section{METODE PENELITIAN}

Penelitian ini menggunakan metode penelitian kualitatif dengan pendekatan studi kasus serta dikembangkan melalui taksonomi bloom. Yin (2003: 13) mendeskripsikan bahwa studi kasus merupakan penyelidikan empiris yang menyelidiki fenomena kontemporer dalam konteks kehidupan nyata, terutama jika batasan antara fenomena dan konteks tidak terlihat jelas.

Atas penjelasan tersebut, pendekatan studi kasus dengan pengembangan taksonomi bloom dinilai tepat untuk memenuhi tujuan dari penelitian ini yaitu untuk menganalisis dan mendeskripsikan perlakuan akuntansi heritage assets serta menganalisis pemahaman entitas pemerintah. Sehingga, dengan menggunakan studi kasus ini isu yang menjadi fokus penelitian, dapat dieksplorasi secara mendalam melibatkan berbagai sumber informasi.

Sumber data yang yaitu sumber data primer dan sekunder. Sumber data primer merupakan sumber data yang pemberiannya langsung kepada pengumpul data (Sugiyono, 2013: 225). Sumber data primer diperoleh dengan cara wawancara kepada para informan dengan karakterisitik bahwa praktisi mengerti, memahami, dan bertanggung jawab atas kebijakan akuntasni heritage assets, terutama berhubungan dengan Balai Pemuda Surabaya. Sehingga dengan adanya kriteria tersebut, maka informan yang dipilih yaitu Bapak Totok selaku Staff Bagian Kebudayaan Dinas Kebudayaan dan Pariwisata Kota Surabaya, Ibu Ika dan Bapak Agung sebagai Staf UPTD Balai Pemuda Surabaya, Bapak Didik sebagai staf pengurus barang Dinas Kebudayaan dan Pariwisata Kota Surabaya, Ibu Silfy sebagai Staff Sub Bagian Keuangan Dinas Kebudayaan dan Pariwisata Kota Surabaya, Bapak Heddy dan Ibu Laily sebagai Staff Bagian Layanan Pengadaan dan Pengelolaan Aset Kota Surabaya. Sedangkan sumber data sekunder adalah sumber yang didapatkan melalui orang lain maupun melalui dokumen (Sugiyono, 2013: 225). Penelitian ini menggunakan sumber data sekunder berasal dari dokumen dan catatan arsip Dinas Kebudayaan dan Pariwisata Kota Surabaya, dokumen Bagian Layanan Pengadaan dan Pengelolaan Aset Kota Surabaya, serta peraturan-peraturan terkait.

Pengumpulan data dilakukan dengan wawancara, dikarenakan peneliti ingin mengetahui hal-hal dari responden yang lebih mendalam terkait dengan perlakuan akuntansi heritage assets baik pengakuan, pengukuran, penilaian, penyajian, pengungkapan serta pemahaman entitas pemerintah berkaitan dengan heritage assets. Kedua, dokumentasi dikarenakan untuk memahami secara lebih baik terkait dengan perlakuan akuntansi heritage assets Balai Pemuda Surabaya baik pengakuan, pengukuran, penilaian, penyajian, dan pengungkapan.

Langkah berikutnya yaitu triangulasi. Penelitian ini menggunakan triangulasi teknik dan triangulasi sumber. Triangulasi teknik bertujuan untuk menguji kredibilitas data, hal ini dilakukan dengan mengecek data kepada sumber yang sama dengan teknik yang berbeda (Sugiyono, 2013: 241). Triangulasi sumber bertujuan untuk menguji kredibilitas data, hal ini dilakukan dengan mengecek data yang telah diperoleh melalui beberapa sumber (Sugiyono, 2013: 274).

Teknik analisis data pada penelitian ini menggunakan Miles dan Huberman (1994: 10) meliputi data reduction (reduksi data), data display (penyajian data), dan conclusion drawing/verification (penarikan kesimpulan). 


\section{ANALISIS DAN PEMBAHASAN \\ Balai Pemuda}

Balai Pemuda Surabaya merupakan salah satu gedung bersejarah yang dilindungi oleh Pemerintah Kota Surabaya. Gedung Balai Pemuda yang menjadi aset bersejarah yaitu Gedung Barat dan Gedung Merah Putih. Kedua gedung tersebut menjadi fokus pada penelitian ini. Gedung tersebut kini telah menjadi pusat kreativitas budaya warga Kota Surabaya, Pusat Informasi Kepariwisataan Surabaya (Surabaya Tourism Promotion Board/STPB), penunjang operasional pemerintah, serta berkontribusi pada pendapatan asli daerah melalui tarif sewa bangunan.

\section{Definisi dan Karakteristik Heritage assets dalam Perspektif Pengelola}

Tingginya peranan pengelola dalam memahami makna dan karakteristik heritage assets dinilai sangat penting. Hal ini dikarenakan adanya pemberian batasan berupa makna dan karakteristik dari suatu ungkapan diharapkan dapat memberikan penjelasan secara rinci dan terhindar dari subjektivitas makna.

Berdasarkan atas hasil wawancara, informan menyatakan bahwa heritage assets (aset bersejarah) merupakan aset yang memiliki hubungan antara nilai budaya, nilai sejarah, ilmu pengetahuan, agama, sehingga harus dilindungi oleh peraturan dan pemerintah. Pemaknaan atas definisi heritage assets oleh para informan didukung oleh Barton (2000) bahwa aset warisan merupakan aset yang memiliki kepentingan sejarah dan budaya yang tinggi, oleh sebab itu harus dijaga dan dipertahankan dalam kondisi baik agar dapat terus menawarkan manfaat sosial mereka untuk jangka waktu yang tidak terbatas.

Atas adanya pemaknaan tersebut, secara eksplisit dapat disimpulkan bahwa pemaknaan definisi heritage assets sejalan dengan PSAP Nomor 07 Tahun 2010. Pernyataan tersebut menyatakan bahwa heritage assets yaitu beberapa aset tetap dijelaskan sebagai aset bersejarah dikarenakan kepentingan budaya, lingkungan, dan sejarah.

Mengenai atas adanya pemahaman terkait definisi dari heritage assets, tentunya sangat memiliki hubungan erat dengan beberapa karakteristik suatu aset tetap agar dapat digolongkan menjadi heritage assets. Berdasarkan atas hasil wawancara dengan Bapak Didik menyatakan bahwa:

"Iya, ada hemm. Seperti misalnya bangunan tersebut harus memiliki nilai budaya, terus aset tersebut harus bisa dilindungi, dirawat, dipelihara, terus ada semacam kayak terdapat larangan atau pembatasan yang sah menurut undangundang untuk masuk ke dalam penjualan".

Sejalan dengan pernyataan tersebut, Bapak Heddy dan Ibu Laily juga menyatakan:

"Ya, itu tadi. Dia memiliki nilai budaya yang sangat tinggi dan dia sudah berumur eh ratusan tahun lebih ya biasanya kalau kriterianya suatu bangunan tersebut bersejarah itu".

Ibu Silfy sebagai Staff Sub Bagian Keuangan Dinas Kebudayaan dan Pariwisata Kota Surabaya menyatakan, yaitu:

"Mempunyai nilai sejarah, nilai budaya, dan dicatat di Dinas Pariwisata (ada bidang terkait Cagar Budaya)"

Berdasarkan atas hasil wawancara di atas bersama dengan Bapak Didik, Bapak Heddy, Ibu Laily, dan Ibu Silfy dapat disimpulkan bahwa informan memahami karakteristik heritage assets yaitu apabila suatu aset memiliki nilai sejarah, nilai budaya, dilindungi, dirawat, dipelihara, adanya larangan atau pembatasan berdasarkan Undang-Undang untuk dijual, dan berumur ratusan tahun. Atas pernyataan tersebut, dapat disimpulkan jika pemahaman narasumber terkait karakteristik heritage assets sejalan dengan karakteristik heritage assets yang tersaji di PSAP Nomor 07 Tahun 2010.

Berbeda dengan narasumber sebelumnya, Bapak Totok memahami karakteristik aset tergolong dalam heritage assets yaitu apabila aset tersebut memiliki usia minimal 50 tahun, mempunyai nilai sejarah, mewakili gayanya, serta unik. Sebagaimana diutarakan dalam wawancaranya:

"Sama ya, ya kalau menurut saya ya itu 
minimal kan usianya 50 tahun ya, kalau cagar budaya loh ya, mempunyai nilai sejarah lah sama kalau bangunan itu aset kan memiliki keunikan. Mewakili gayanya, ciri khas gayanya pada waktu dulu itu seperti apa. Unik lah istilahnya, gak ada. Gak ada apa, gak ada duanya”.

Sebagai staf cagar budaya dan sejarah yang berpedoman pada UndangUndang Republik Indonesia Nomor 11 Tahun 2010, oleh sebab itu Bapak Totok mendeskripsikan karakteristik heritage assets berdasarkan atas Undang-Undang Republik Indonesia Nomor 11 Tahun 2010 dinyatakan bahwa kriteria benda, bangunan, atau struktur dapat diusulkan sebagai benda cagar budaya, bangunan cagar budaya, atau struktur cagar budaya, yaitu:

a. Berusia 50 (lima puluh) tahun atau lebih;

b. mewakili masa gaya paling singkat berusia 50 (lima puluh) tahun;

c. memiliki arti khusus bagi sejarah, ilmu pengetahuan, pendidikan, agama, dan/ atau kebudayaan; dan

d. memiliki nilai budaya bagi penguatan kepribadian bangsa.

Dengan demikian, dapat disimpulkan bahwa heritage assets merupakan bagian dari cagar budaya. Hal ini dikarenakan aset bersejarah memenuhi kriteria sebagai aset yang memiliki nilai budaya, pendidikan yang tinggi sehingga adanya larangan atau batasan secara ketat untuk dijual sebagai penguatan kepribadian bangsa.

\section{Perlakuan Akuntansi Heritage assets Balai Pemuda dalam Sudut Pandang Entitas Pemerintah dan Laporan Keuangan}

Penelitian ini menganalisis bagaimana perlakuan akuntansi heritage assets Balai Pemuda terkait dengan pengakuan, pengukuran, penilaian, penyajian, dan pengungkapan.

\section{Pengakuan Heritage assets}

Pengakuan adalah proses penetapan terpenuhinya kriteria pencatatan suatu kejadian atau peristiwa dalam catatan akuntansi sehingga akan menjadi bagian yang melengkapi unsur aset, kewajiban, ekuitas, pendapatan-LRA, belanja, pembiayaan, pendapatan-LO, dan beban, sebagaimana akan termuat pada laporan keuangan entitas pelaporan yang bersangkutan (PSAP Nomor 01 Tahun 2010 paragraf 84).

Berdasarkan atas hasil penelitian di Balai Pemuda, Pemerintah Kota Surabaya mengakui heritage assets sebagai aset dan termasuk dalam akun aset tetap. Diakuinya Balai Pemuda sebagai aset tetap dikarenakan bahwa Pemerintah Kota Surabaya memperlakukan heritage assets sama dengan aset tetap pada umumnya.

Pada kasus Balai Pemuda, diakuinya Balai Pemuda sebagai aset tetap juga dimulai semenjak adanya SK Walikotamadya Kepala Daerah Tingkat II Surabaya Nomor: 188.45/251/402.1.104/ 1996. Diakuinya heritage assets Balai Pemuda sebagai aset Pemerintah Kota Surabaya dikarenakan bahwa adanya misi penyelamatan pada peninggalan Hindia Belanda, oleh karenanya Pemerintah Kota Surabaya mengambil alih bangunan dan ditetapkan menjadi aset daerah.

Telah tepat diakuinya heritage assets Balai Pemuda sebagai aset tetap juga dikarenakan bahwa selain adanya manfaat sosial, budaya, pendidikan, Balai Pemuda Surabaya juga memberikan aliran pendapatan bagi Pemerintah Kota Surabaya melalui kegiatan sewa menyewa.

Hal ini sejalan dengan penelitian Widodo et al. (2020) atas adanya manfaat ekonomi yang dihasilkan oleh heritage assets di masa mendatang dan heritage assets juga merupakan sesuatu yang dimiliki oleh suatu entitas oleh karenanya heritage assets diakui sebagai aset.

Pengakuan heritage assets Balai Pemuda sebagai aset tetap juga dikarenakan bahwa berpedomaan pada PSAP Nomor 07 Tahun 2010 yang menyatakan bahwa heritage assets merupakan aset tetap. Sehingga, dapat disimpulkan bahwa Pemerintah Kota Surabaya telah tepat mengakui heritage assets Balai Pemuda sebagai aset tetap seperti yang telah disampaikan dalam PSAP Nomor 07 Tahun 2010.

\section{Pengukuran Heritage assets}

Agustini \& Putra (2011) menyatakan bahwa pengukuran yaitu proses menentukan nilai 
ekonomi secara finansial berdasarkan terjadinya suatu aset atau pada saat awal aset diperoleh yang nantinya diletakkan pada suatu objek.

Berdasarkan atas hasil penelitian, pengukuran awal atau penentuan nilai ekonomi secara finansial atas heritage assets Gedung Barat dan Gedung Merah Putih Balai Pemuda telah dilakukan oleh Pemerintah Kota Surabaya. Sebagaimana tersaji pada Tabel 1. Dilakukannya pengukuran oleh Pemerintah Kota Surabaya juga dikarenakan bahwa adanya kewajiban dari BPK agar Pemerintah Kota Surabaya melakukan pengukuran pada semua aset tetap, baik aset tetap bersejarah maupun aset tetap tidak bersejarah.

Telah dilakukannya pengukuran pada heritage assets Balai Pemuda sehingga dapat dinilai bahwa Pemerintah Kota Surabaya telah mampu menjalankan prinsip akuntansi akrual di sektor publik dengan baik, karena entitas pemerintahdapat mengidentifikasi dan menilai aset tetap agar dapat menyusun neraca. Hal ini sejalan dengan penelitian Sumber: Kertas kerja koreksi pencatatan aset gedung dan bangunan Dinas Ke- budayaan dan Pariwisata.

Basnan et al. (2015) yang menyatakan bahwa di bawah akuntansi berbasis akrual semua aset dapat diukur secara wajar, mereka harus diakui dan diungkapkan dalam pernyataan posisi keuangan pemerintah.

Adanya pengukuran awal pada heritage assets Balai Pemuda juga telah tepat dilakukan karena melihat kondisi nyata di lapangan, heritage assets Balai Pemuda memberikan potensi manfaat lainnya kepada pemerintah untuk ruang perkantoran, maka Balai Pemuda diterapkan prinsip seperti aset tetap lainnya, salah satunya yaitu pengukuran awal. Hal ini sebagaimana telah dijelaskan pada PSAP Nomor 07 Tahun 2010 paragraf 71.

\section{Penilaian Heritage assets}

Penilaian adalah penentuan nilai ekonomi suatu objek, pos, atau elemen (Statement of Financial Accounting Concept Nomor 5). Penilaian aset merupakan suatu proses dalam menentukan jumlah rupiah yang nantinya diletakkan pada tiap elemen atau pos keuangan pada saat penyajian laporan keuangan.

Berdasarkan atas hasil penelitian,

Tabel 1.

Pengukuran Awal Gedung Merah Putih dan Gedung Barat

\begin{tabular}{|c|c|c|c|}
\hline No & Lokasi & Nama Barang & Nilai Perolehan \\
\hline 1 & $\begin{array}{l}\text { Kantor UPTD Balai } \\
\text { Pemuda dan GNI }\end{array}$ & Gedung Merah Putih & Rp. 6.109.139.650,00 \\
\hline 2 & $\begin{array}{l}\text { Kantor UPTD Balai } \\
\text { Pemuda dan GNI }\end{array}$ & $\begin{array}{l}\text { Gedung Barat Balai } \\
\text { Pemuda }\end{array}$ & Rp. 1.244.369.605,00 \\
\hline
\end{tabular}

Sumber: kertas kerja koreksi pencatatan aset Gedung dan bangunan Dinas Kebudayaan dan Pariwisata.

Tabel 2.

Penilaian Gedung Merah Putih atas Kapitalisasi Biaya

\begin{tabular}{|c|c|c|c|}
\hline No & Tahun & Nama Barang & Nilai Perolehan \\
\hline 1 & 1945 & Gedung Barat Balai Pemuda & Rp. 1.244.369.605 \\
\hline \multirow[t]{2}{*}{2} & 2013 & Gedung Balai Pemuda & Rp. 8.392.414.977,61 \\
\hline & & Total Nilai & Rp. 9.636.784.582,61 \\
\hline
\end{tabular}

Sumber: kertas kerja koreksi pencatatan aset Gedung dan bangunan Dinas Kebudayaan dan Pariwisata. 
penilaian atas nilai yang disajikan pada laporan keuangan Pemerintah Kota Surabaya berasal dari pengukuran awal atas Balai Pemuda dan adanya penambahan dari nilai kapitalisasi. Penambahan nilai atas kapitalisasi tersebut akan menambah nilai Balai Pemuda jika biaya pemeliharaan telah melebihi suatu batasan dari jumlah biaya kapitalisasi. Besaran batasan biaya kapitalisasi tersebut mengacu pada Peraturan Walikota Nomor 10 Tahun 2016 Tentang Perubahan Kedua Atas Peraturan Walikota Surabaya Nomor 32 Tahun 2014 Tentang Kebijakan Akuntansi Pemerintah Kota Surabaya. Diakuinya Balai Pemuda sebagai gedung dan bangunan, oleh karenanya batasan kapitalisasi yang ditentukan yaitu sebesar lebih dari 25 juta. Atas hasil penelitian diperoleh data bahwa heritage assets Balai Pemuda pernah dilakukan penambahan nilai atas kapitalisasi biaya yang dikeluarkan. Hal tersebut dapat terlihat pada Tabel 2 dan Tabel 3.

Hasil penelitian atas penilaian Balai Pemuda ini sejalan dengan penelitian yang dilakukan oleh Basnan et al. (2015) mengungkapkan bahwa pemerintah melakukan kapitalisasi pada heritage assets jika biaya atau nilai wajarnya dapat diukur andal dengan memperhitungkan nilai-nilai sejarah, artistik, dan budaya serta adanya peningkatan nilai pada heritage assets, agar laporan keuangan lebih tersaji dengan tepat.

Perlakuan akuntansi penilaian heritage assets Balai Pemuda pada Gedung Barat dan Gedung Merah Putih Balai Pemuda yang dilakukan oleh Pemerintah Kota Surabaya juga telah sesuai dengan PSAP Nomor 07 Tahun 2010 yaitu atas kapitalisasi biaya pengeluaran telah melebihi suatu batasan biaya maka akan menambah nilai aset tersebut.

\section{Penyajian Heritage assets}

Penyajian merupakan tahap pelaporan suatu pos pada laporan keuangan. Penyajian merupakan bentuk pertanggungjawaban pemerintah atas pengelolaan pospos tersebut (Agustini \& Putra, 2011). Pemerintah Kota Surabaya memperlakukan heritage assets sama dengan aset tetap pada umumnya. Atas adanya persamaan perlakuan akuntansi seperti aset tetap pada umumnya, oleh sebab itu heritage assets disajikan pada neraca dengan nilai. Sesuai dengan kriterianya, Gedung Barat dan Gedung Merah Putih Balai Pemuda disajikan pada neraca ke dalam akun aset

Tabel 3.

Penilaian Gedung Barat Balai atas Kapitalisasi Biaya

\begin{tabular}{|c|c|c|c|}
\hline No & Tahun & Nama Barang & Nilai Perolehan \\
\hline 1 & 1945 & Gedung Merah Putih & Rp. 6.109.139.650 \\
\hline \multirow[t]{2}{*}{2} & 2015 & Pembangunan gedung type A & Rp. 4.299.305.950 \\
\hline & & Total Nilai & Rp. 10.408 .445 .600 \\
\hline
\end{tabular}

Sumber: kertas kerja koreksi pencatatan aset Gedung dan bangunan Dinas Kebudayaan dan Pariwisata.

Tabel 4.

Kartu Inventaris Barang (KIB)-2020 Gedung dan Bangunan

\begin{tabular}{llcc}
\hline \multirow{2}{*}{ No } & \multicolumn{1}{c}{ Jenis/Nama } & Kode Neraca & Harga \\
\hline \multirow{2}{*}{1} & Gedung Barat Balai Pemuda & $\begin{array}{c}1.3 .3 .0 \\
1.27\end{array}$ & Rp. 9.636.784.582,61 \\
& Gedung Merah Putih Balai & 1.3 .3 .0 & Rp. $10.408 .445 .600,00$ \\
2 & Pemuda & 1.27 & \\
\hline
\end{tabular}

Sumber: Kartu Inventaris Barang Surabaya 
tetap sub akun gedung dan bangunan.

Pernyataan tersebut juga telah dikonfirmasi dengan adanya kartu inventaris barang, heritage assets gedung barat balai pemuda dan gedung merah putih memiliki kode akun neraca 1.3.3.01.27 sebagaimana terlihat pada Tabel 4.

Atas kode akun 1.3.3.01.27 menyatakan bahwa heritage assets tersebut termasuk dalam aset tetap gedung dan bangunan. Hal tersebut didasarkan pada Lampiran III Peraturan Menteri Dalam Negeri Republik Indonesia Nomor 64 Tahun 2013 Tentang Penerapan Standar Akuntansi Pemerintahan Berbasis Akrual Pada Pemerintah Daerah. Menandakan bahwa kode akun 1.3.3 tergolong dalam aset gedung dan bangunan.

Dapat dianalisis bahwa adanya penyajian ini merupakan akibat setelah proses pengukuran dan penilaian pada Balai Pemuda. Hasil penelitian ini selaras dengan penelitian Agustini \& Putra (2011) bahwa apabila pemerintah telah berhasil melakukan proses pengakuan, pengukuran, dan penilaian pada aset bersejarah maka final action yang harus dilakukan yaitu penyajian aset bersejarah dalam laporan keuangan pemerintah.

Melihat kondisi nyata di lapangan, Balai Pemuda tidak hanya dimanfaatkan atas nilai sejarah dan budayanya, namun juga digunakan sebagai ruang perkantoran UPTD Balai Pemuda dan tourism sehingga sesuai dengan PSAP Nomor 07 Tahun 2010 maka diharuskan menerapkan prinsipprinsip yang sama seperti aset tetap lainnya, salah satunya yaitu penyajian dengan nilai.

\section{Pengungkapan Heritage assets}

Pengungkapan lengkap adalah laporan keuangan menyajikan secara lengkap informasi yang dibutuhkan oleh pengguna. Informasi yang dibutuhkan oleh pengguna laporan keuangan dapat ditempatkan pada lembar muka (on the face) laporan keuangan atau CaLK (PSAP Nomor 4 Tahun 2010).

Berdasarkan atas hasil penelitian, setelah adanya penyajian heritage assets Balai Pemuda di neraca dengan nilai,
Pemerintah Kota Surabaya juga telah mengungkapkan Balai Pemuda di CaLK dengan nilai. Pengungkapan atas Balai Pemuda tersebut tidak diperlakukan secara terperinci, namun Pemerintah Kota Surabaya hanya sebatas mengungkapkannya dengan nilai secara global dalam sub akun bangunan gedung untuk tempat kerja lainnya sebagaimana dapat terlihat melalui kode akun 1.3.3.01.27.

Pengungkapan tersebut tidak disertai dengan rincian nama, jenis, kondisi dan lokasi aset. Perincian atas nama dan lokasi hanya terdapat pada Kartu Inventaris Barang (KIB) Kota Surabaya.

Adanya pengungkapan tersebut dapat dianalisis bahwa Pemerintah Kota Surabaya masih belum sepenuhnya menjalankan perlakuan akuntansi heritage assets dengan tepat. Sebagaimana dijelaskan pada PSAP Nomor 07 Tahun 2010 paragraf 83 menyatakan bahwa aset bersejarah diungkapkan secara rinci, antara lain nama, jenis, kondisi, dan lokasi aset dimaksud. Hal ini didukung oleh pendapat Aversano, Christiaens \& Thielen (2018); Basnan et al. (2015); Darmawan et al. (2017) bahwa seharusnya pemerintah menyajikan informasi non-keuangan berupa sifat dan karakteristik dari heritage assets yang dimiliki serta kondisi fisik dan pemeliharaan, agar pengguna dapat mengetahui bagaimana entitas dapat menjaga dan mempertanggungjawabkan aset bersejarah yang dilindungi oleh pemerintah.

\section{Pemahaman Individu Entitas Pengelola atas Perlakuan Akuntansi Heritage as- sets Balai Pemuda}

Penelitian ini bertujuan untuk menganalisis pemahaman individu pengelola Balai Pemuda atas adanya pengakuan, pengukuran, penilaian, penyajian, dan pengungkapan heritage assets Balai Pemuda.

\section{Pemahaman Individu Entitas Pengelola atas Pengakuan Heritage assets}

Pemahaman entitas pengelola terkait pengakuan heritage assets sangat dibutuhkan agar entitas pengelola dapat mengerti dan memahami sepenuhnya atas 
proses pengakuan heritage assets.

Berdasarkan atas hasil wawancara dapat dianalisis bahwa informan telah memahami dan mengerti materi secara keseluruhan. Bloom (1956) berdasarkan atas taksonominya, menyatakan bahwa pemahaman tingkat kedua atau pemahaman interpretasi telah dapat dicapai apabila individu telah memiliki kemampuan memahami dan mengerti sesuatu secara keseluruhan pada setiap materi.

Telah dicapainya tingkat interpretasi ini dapat terlihat pada saat informan mampu menjelaskan pertanyaan wawancara mengapa heritage assets Balai Pemuda dapat diakui sebagai aset. Hal ini dijelaskan bahwa para informan menggolongkan heritage assets Balai Pemuda dalam aset tetap pada umumnya. Diakuinya heritage assets sebagai aset tetap dikarenakan bahwa heritage assets Balai Pemuda memiliki ciri seperti aset tetap yaitu biaya perolehan dapat diukur secara andal, bertahan selama setahun lebih, digunakan, dan memiliki manfaat ekonomi sebagai retribusi daerah.

Sebagaimana dipahami dan dimengerti ciri heritage assets Balai Pemuda seperti yang telah diutarakan oleh para informan tersebut, sehingga secara eksplisit pengelola telah memahami PSAP Nomor 07 Tahun 2010 atas kriteria aset yang diakui sebagai aset tetap.

Hasil penelitian ini sejalan dengan penelitian Agustini \& Putra (2011) yang menyatakan bahwa atas aset bersejarah yang berfungsi untuk memperoleh potensi jasa atau manfaat ekonomi harus diakui sebagai aset dalam laporan keuangan pemerintah.

\section{Pemahaman Individu Entitas Pengelola atas Pengukuran Heritage assets}

Berdasarkan atas hasil penelitian, pengelola memahami bahwa heritage assets Balai Pemuda tepat untuk dilakukan pengukuran dengan nilai. Hal ini dikarenakan bahwa atas adanya potensi manfaat lainnya yang diberikan kepada pemerintah seperti adanya retribusi daerah maka pengukuran tepat dilakukan di Balai Pemuda. Dijadikannya objek wisata dan dapat meningkatkan perekonomian juga menjadi alasan untuk dilakukannya pengukuran pada heritage assets. Dipahaminya heritage assets seperti aset tetap pada umumnya juga membuat pengukuran dengan nilai, tepat untuk dilakukan di Balai Pemuda.

Sehingga dapat dianalisis, telah mampu menjelaskan, memahami, dan mengerti atas pertanyaan wawancara mengapa heritage assets Balai Pemuda dapat dilakukan pengukuran sebagaimana yang telah dijabarkan di atas. Oleh sebab itu, pengelola telah mencapai pemahaman tingkat kedua. Pemahaman tingkat kedua atau pemahaman interpretasi yaitu individu mampu menjelaskan, memahami dan mengerti sesuatu seara keseluruhan pada setiap materi (Bloom, 1956).

Telah dicapainya pemahaman tingkat kedua juga dikarenakan bahwa pengelola telah memahami keseluruhan materi pada PSAP Nomor 07 Tahun 2010 yaitu jika heritage assets memiliki potensi manfaat lainnya kepada pemerintah selain nilai sejarahnya, oleh sebab itu aset ini akan diterapkan prinsip-prinsip yang sama seperti aset tetap lainnya.

Dipahaminya prinsip pengukuran oleh pengelola, seharusnya juga diimbangi dengan metode pengukuran yang relevan untuk heritage assets Balai Pemuda. Berdasarkan atas hasil wawancara, para informan menyampaikan bahwa metode pengukuran heritage assets Balai Pemuda dilakukan dengan menggunakan metode biaya perolehan.

Namun jika disesuaikan dengan PSAP Nomor 07 Tahun 2010, pernyataan tersebut menyatakan bahwa "barang berwujud yang memenuhi kualifikasi untuk diakui sebagai suatu aset dan dikelompokkan sebagai aset tetap, pada awalnya harus diukur berdasarkan biaya perolehan. Bila aset tetap diperoleh dengan tanpa nilai, biaya aset tersebut adalah sebesar nilai wajar pada saat aset tersebut diperoleh".

Atas kondisi nyata bahwa Balai Pemuda diperoleh dengan tanpa nilai, yaitu berasal dari peninggalan Belanda yang ada di Kota Surabaya sehingga seharusnya entitas pengelola memahami bahwa metode pengukuran yang tepat yaitu nilai 
wajar.

Adanya ketidaksesuaian pemahaman pengelola dengan PSAP NOMOR 07 Tahun 2010, dapat disimpulkan bahwa pengelola masih berada pada level pengetahuan. Bloom menyatakan bahwa tingkat pengetahuan yaitu individu mengetahui sekaligus menyampaikan ingatan berupa menyebutkan dan menyatakan saja dan masih belum sepenuhnya memahami materi secara keseluruhan yaitu PSAP Nomor 07 Tahun 2010.Belum sampainya pada level pemahaman, juga dikarenakan bahwa metode pengukuran atas heritage assets ditentukan oleh kurator (pihak ketiga).

\section{Pemahaman Individu Entitas Pengelola atas Penilaian Heritage assets}

Berdasarkan atas hasil penelitian wawancara, para informan memahami berbeda-beda atas nilai moneter yang nantinya diletakkan pada laporan keuangan.

Berdasarkan atas hasil wawancara terkait dengan pertanyaan bagaimana melakukan penilaian heritage assets Balai Pemuda yang nantinya disajikan di laporan keuangan. Bapak Heddy dan Ibu Silfy hanya dapat menyatakan bahwa penilaian disajikan dengan biaya perolehan. Sehingga, atas adanya pendapat tersebut, hal ini dapat disimpulkan bahwa informan tersebut masih belum sepenuhnya memahami atas perlakuan akuntansi heritage assets sebagaimana yang telah ada di laporan keuangan Kota Surabaya dan atas materi perlakuan akuntansi penilaian heritage assets sesuai dengan PSAP Nomor 07 tahun 2010 paragraf 49-50.

Sehingga dapat dianalisis berdasar atas penjelasan di atas, Bapak Heddy dan Ibu Silfy masih berada pada tingkat pengetahuan. Bloom (1956) menyatakan tingkat pengetahuan yaitu sebatas mengetahui dan menyampaikan ingatan berupa menyebutkan dan menyatakan, dan belum sepenuhnya memahami keseluruhan atas materi.

Berbeda dengan informan sebelumnya, Bapak Didik mampu menjelaskan bahwa atas nilai heritage assets yang terkandung dalam laporan keuangan yaitu pertama dari pengukuran awal dan penambahan nilai kapitalisasi atas biaya pengeluaran yang telah melebihi ketentuan. Pemahaman yang disampaikan oleh Bapak Didik tersebut telah sesuai dengan PSAP Nomor 07 Tahun 2010 paragraf 49-50. Oleh karena itu, telah dipahaminya materi secara keseluruhan, maka dapat dianalisis jika Bapak Didik telah mencapai pemahaman interpretasi. Pemahaman interpretasi dapat dicapai ketika individu mampu menjelaskan atas materi yang dimaksud, serta memahami dan mengerti sesuatu secara keseluruhan pada setiap materi (Bloom, 1956).

\section{Pemahaman Individu Entitas Pengelola atas Penyajian Heritage assets}

Setelah adanya proses pengakuan, pengukuran, penilaian atas heritage assets, maka langkah selanjutnya yaitu menyajikan heritage assets pada laporan keuangan pemerintah. Adanya penyajian heritage assets di laporan keuangan yaitu sebagai bentuk pertanggungjawaban atas pengelolaan aset publik. Perlunya disajikan aset tetap dalam neraca, karena dinilai aset tetap merupakan suatu bagian utama aset pemerintah.

Berdasarkan atas hasil penelitian dapat disimpulkan bahwa para informan memiliki pemahaman pada tingkat yang berbeda.

Bapak Didik menyampaikan bahwa:

"Iya, kita melaporkan, kalau laporan keuangannya ya kita melaporkan ke bagian keuangan apa data kita, terus nanti bagian keuangan yang menjurnal di badan pengelolaan keuangan, nanti dari itu keluar neraca". "Kalau akunnya bilangnya akunnya tempat kerja nanti akunnya ngumpul jadi satu secara global, nanti berdasarkan akun".

Sejalan dengan pemahaman tersebut, Ibu Laily selaku informan juga memberikan pendapat bahwa:

"Ada karena kita kan harus laporan keuangan (neraca), kan aset tetap harus dapat dinilai kan, kriteria aset tetap". "Ada gedung bangunan tempat kerja, gedung bangunan sejarah kayak gitu ada. Tapi kalau di neraca kita mencatatnya aset tetap tanah itu berapa nilai nya, aset tetap gedung bangunan itu berapa. Itu masuk aset tetap gedung bangunan kalau balai pemuda". 
Atas hasil wawancara tersebut, dapat dianalisa bahwa hasil berdasarkan atas pertanyaan mengapa heritage assets Balai Pemuda disajikan di laporan keuangan, para informan telah memahami secara keseluruhan yaitu setelah adanya proses melaporkan nilai heritage assets maka langkah selanjutnya yaitu menyajikan laporan keuangan.

Oleh sebab itu, Ibu Laily dan Bapak Didik telah mampu mencapai pemahaman tingkat interpretasi. Hal tersebut dicapai karena individu telah memiliki kemampuan memahami dan mengerti sesuatu secara keseluruhan pada setiap materi (Bloom, 1956). Berdasarkan atas

Berbeda dengan sebelumnya, Ibu Silfy hanya mampu menyampaikan ingatan berupa menyebutkan dan menyatakan jika heritage assets disajikan di neraca dengan nama akun gedung dan bangunan. Sebagaimana disampaikan berdasarkan hasil wawancara:

"Ya karena nantinya akan disajikan dengan nama akun gedung dan bangunan".

Hal ini sebagaimana dijelaskan oleh bloom bahwa tingkat pengetahuan yaitu jika individu hanya menyampaikan ingatan berupa menyebutkan dan menyatakan (Bloom, 1956). Belum tercapainya tingkat pemahaman juga disebabkan bahwa Ibu Silfy masih belum menjelaskan keseluruhan materi atas pertanyaan mengapa heritage assets tepat untuk dilakukan penyajian di neraca.

\section{Pemahaman Individu Entitas Pengelola atas Pengungkapan Heritage assets}

Pemahaman pengungkapan dinilai penting, hal ini dikarenakan agar penyediaan informasi kepada stakeholder nantinya dapat memberikan informasi yang relevan. Pengungkapan ini berkaitan dengan CaLK. Terlebih berdasarkan hasil penelitian, Pemerintah Kota Surabaya masih belum mengungkapan heritage assets pada CaLK sebagaimana sesuai dengan kebijakan PSAP Nomor 07 Tahun 2010.

Berdasarkan atas hasil wawancara, pengelola menyampaikan bahwa setelah disajikannya heritage assets secara global pada neraca, maka langkah selanjutnya yaitu mengungkapkan di CALK. Nantinya informasi yang diungkapkan dituliskan secara terperinci dan lebih khusus.

Berdasarkan atas pemahaman tersebut, dapat dianalisis bahwa pemahaman entitas pengelola mencapai pada pemahaman terjemah. Atas adanya pemahaman pemberian makna pada suatu komunikasi tersebut dapat terlihat ketika informan menyatakan bahwa pengungkapan heritage assets yaitu adanya penjelasan secara rinci atas aset pada CaLK.

Masih berada pada tingkat pemahaman terjemah juga dikarenakan para informan masih belum sepenuhnya memahami keseluruhan materi. Berdasarkan atas PSAP Nomor 07 Tahun 2010 menyatakan aset bersejarah diungkapkan secara rinci, antara lain nama, jenis, kondisi, dan lokasi aset dimaksud.

Adanya pemahaman oleh pengelola bahwa diungkapkannya heritage assets secara rinci pada laporan keuangan seharusnya juga diikuti dengan penerapan pada laporan keuangan Kota Surabaya. Agar nantinya pengungkapan secara rinci tidak hanya berada pada kartu inventaris barang, namun di sajikan juga pada CaLK agar para pengguna dapat membaca informasi non-keuangan atas rincian heritage assets Kota Surabaya dan sesuai dengan kebijakan PSAP Nomor 07 Tahun 2010.

\section{SIMPULAN DAN SARAN}

Hasil penelitian menyimpulkan bahwa, terkait dengan kebijakan akuntansi heritage assets Balai Pemuda Surabaya, maka Pemerintah Kota Surabaya masih belum sepenuhnya memperlakukan heritage assets sesuai dengan PSAP Nomor 07 Tahun 2010, hal ini dikarenakan tidak adanya pengungkapan secara rinci atas nama, jenis, kondisi, dan lokasi aset yang dimaksud. Diharapkan agar Pemerintah Kota Surabaya dapat mengungkapkan secara rinci heritage assets sebagaimana sesuai dengan kebijakan PSAP Nomor 07 Tahun 2010. Pengukuran awal dan penambahan nilai atas Balai Pemuda telah dilakukan sesuai dengan kebijakan akuntansi yaitu jika biaya yang dikeluarkan melebihi batas 
kapitalisasi maka terdapat penambahan nilai heritage assets. Penyajian heritage asset Balai Pemuda juga telah dilakukan di neraca dengan nilai ekonomi atas nama akun gedung dan bangunan.

Pemahaman individu entitas pengelola terkait perlakuan akuntansi heritage assets Balai Pemuda berdasarkan pada PSAP Nomor 07 Tahun 2010 masih berada pada tingkat yang berbeda-beda. Terkait dengan pengakuan dan pengukuran, entitas pengelola memahami bahwa Balai Pemuda seharusnya diakui sebagai aset dan dilakukan pengukuran sebagaimana aset tetap pada umumnya, hal ini karena memiliki ciri seperti aset tetap dan memiliki manfaat ekonomi. Atas adanya pemahaman tersebut, entitas telah berada pada tingkat interpretasi dikarenakan, mengerti dan memahami secara keseluruhan atas kebijakan dalam PSAP Nomor 07 Tahun 2010. Namun terkait dengan metode pengukuran, pengelola masih berada pada tingkat pengetahuan dikarenakan masih belum sepenuhnya memahami metode pengukuran yang mana dijelaskan pada PSAP Nomor 07 Tahun 2010, rendahnya pemahaman juga dikarenakan bahwa pengukuran dilakukan oleh pihak eksternal (pihak kurator). Pemahaman entitas pengelola atas penilaian masih berada pada tingkat yang berbeda-beda, hal ini dikarenakan tidak semua informan memahami adanya penambahan nilai pada aset jika terdapat biaya pengeluaran yang melebihi suatu batasan, sebagaiman dijelaskan pada PSAP Nomor 07 Tahun 2010 dan pada perlakuan akuntansi di laporan keuangan Kota Surabaya. Pemahaman yang berbeda-beda juga terjadi pada penyajian, karena informan tidak sepenuhnya memahami mengapa heritage assets harus dilakukan penyajian di laporan keuangan. Pada saat pengungkapan, entitas telah berada pada pemahaman terjemah yaitu adanya pemberian makna bahwa pengungkapan aset seharusnya dilakukan secara rinci di CaLK dan seharusnya adanya pemahaman tersebut juga diikuti dengan penerapan di CaLK Kota Surabaya

Hasil penelitian secara keseluruhan menyimpulkan bahwa, pertama terkait dengan aset-aset bersejarah juga memberikan potensi manfaat lainnya kepada pemerintah selain nilai sejarahnya, sebagai contoh bangunan bersejarah digunakan untuk ruang perkantoran atau menghasilkan nilai ekonomi. Pemerintah Kota/Daerah harus memperlakukannya sebagaimana aset tetap pada umumnya dan diterapkan sesuai dengan PSAP Nomor 07 Tahun 2010. Perlakuan akuntansi juga seharusnya diimbangi dengan pemahaman tingkat interpretasi, agar pengelola dapat memahami serta menerapkan kebijakan akuntansi heritage asset jauh lebih baik sesuai dengan kebijakan akuntansi PSAP Nomor 07 Tahun 2010.

\section{KETERBATASAN DAN SARAN}

Keterbatasan penelitian yang timbul yaitu salah satu informan penelitian atau seorang kurator tidak dapat dilakukan wawancara, hal ini terhalang adanya masalah perizinan, sehingga informasi yang bersumber dari kurator tidak masuk dalam penelitian ini.

Saran yang diusulkan yaitu pertama diharapkan bagi Pemerintah Kota Surabaya agar dapat mencatat keberadaan heritage assets secara terperinci pada CaLK. Kedua, adanya komunikasi antara pihak eksternal (kurator) dengan pihak pengelola agar pemahaman terkait metode pengukuran awal atas heritage assets Balai Pemuda dapat diketahui secara relevan. Ketiga, adanya seminar atas perlakuan akuntansi heritage assets agar semua pihak pengelola dapat memahami secara utuh perlakuan akuntansinya. Keempat, bagi peneliti selanjutnya, peneliti menyarankan agar memperluas cakupan penelitian mengenai perlakuan akuntansi atas heritage assets di Indonesia karena kebijakan akuntansi heritage assets memiliki perlakuan berbeda -beda sesuai dengan kebijakan pemerintah daerah masing-masing.

\section{DAFTAR PUSTAKA}

Agustini, A.T., \& Putra, H.S. (2011). Aset bersejarah dalam pelaporan keuangan entitas pemerintah. Jurnal Ekonomi Akuntansi Dan Manajemen, 10(1).

Anessi-pessina, E., Cattolica, U., \& 
Steccolini, I. (2020). Heritage: The priceless hostage of accrual accounting. International Journal of Public Sector Management, 33(2), 285 $-306$.

Aversano, N., Christiaens, J., \& Thielen, T. Van. (2018). Does IPSAS meet heritage assets' user needs?. International Journal of Public Administration, 42 (4), 279-288.

Basnan, N., Salleh, M.F., Ahmad, A., Harun, A. M., \& Upawi, I. (2015). Challenges in accounting for heritage assets and the way forward: Towards implementing accrual accounting in Malaysia. Malaysian Journal of Society and Space, 11(11), 63-73.

Biondi, L., \& Lapsley, I. (2010). Accounting, transparency, and governance: The heritage assets problem.

Bloom, B.S. (1956). Taxonomy of educational objectives. (Vol. 1: Cognitive domain). New York: McKay.

Darmawan, C.B., Yadnyana, I.K., \& Sudana, I. P. (2017). Menguak perlakuan akuntansi aset bersejarah (Studi interpretif pada Museum Semarajaya Klungkung). E-Jurnal Ekonomi Dan Bisnis Universitas Udayana, 5, 17851816.

Ellwood, S., \& Greenwood, M. (2015). Critical Perspectives on Accounting Accounting for heritage assets: Does measuring economic value 'kill the cat'? Critical Perspectives on Accounting.

Lukman, A. (2020). Community-based management of the USAT Liberty, Bali, Indonesia: Pathways to sustainable cultural heritage tourism. Journal of Cultural Heritage Management and Sustainable Development, 10(3), 217-231.

Miles, M.B., \& Huberman, A.M. (1994). Qualitative data analysis: An expanded sourcebook. Sage.

Ouda, H.A.G. (2005). Transition to accrual accounting in the public sector of developed and developing countries: Problems and Requirements. with special focus on the netherlands and egypt. Universal Press.

Ouda, H.A.G. (2014). Towards a practical accounting approach for heritage assets: An Alternative Reporting Model for the NPM Practices. Journal of Finance and Accounting, 2(2), 1933.
Ouda, H.A.G. (2014). A practical accounting approach for heritage assets under accrual accounting: With special focus on egypt a practical accounting approach for heritage assets under accrual accounting: With special focus on Egypt. International Journal of Governmental Financial Management, XIV(2).

Sugiyono, P. (2013). Metodologi penelitian kuantitatif kualitatif dan $R \& D$. Bandung: Alpabeta..

Widodo, H., Hanun, N.R., \& Wulandari, R. (2020). Accounting treatment for heritage assets: A case study on management of Pari Temple, 21(1).

Wild, S. (2013). Accounting for heritage, cultural and community assetsalternative metrics from a New Zealand Māori Educational Institution. Australasian Accounting, Business and Finance Journal, 7, 3-22.

Woon, P.P., Chatterjee, B., \& Cordery, C.J. (2019). Heritage reporting by the Australian public sector: Possibilities from the concepts of new public governance. Accounting, Auditing and Accountability Journal, 32(2), 612631.

Wulandari, D., \& Utama, A.A. (2017). Looking at recognition, valuation, presentation and disclosure of historical assets at nganjuk museum. Advanced Science Letters, 23(9), 9191 $-9194$.

Yin, R.K. (2003). Applied social research methods series. In Case study research: Design and methods (Vol. 5). Thousand Oaks: Sage.

Peraturan Walikota Nomor 10 Tahun 2016 Tentang Perubahan Kedua Atas Peraturan Walikota Surabaya Nomor 32 Tahun 2014 Tentang Kebijakan Akuntansi Pemerintah Kota Surabaya. 29 Maret 2016. Surabaya

Peraturan Pemerintah Republik Indonesia Nomor 71 Tahun 2010 Tentang Standar Akuntansi Pemerintah. 22 Oktober 2010. Jakarta

Peraturan Menteri Dalam Negeri Republik Indonesia Nomor 64 Tahun 2013 tentang Penerapan Standar Akuntansi Pemerintahan Berbasis Akrual pada Pemerintah Daerah. 6 Desember 2013. Jakarta.

Undang-Undang Republik Indonesia Nomor 11 Tahun 2010 tentang Cagar Budaya. 24 November 210. Jakarta 